\title{
Development of competences while solving real industrial interdisciplinary problems: a successful cooperation with industry
}

\author{
Rui Manuel Limaa*, José Dinis-Carvalho ${ }^{\mathrm{a}}$, Rui Manuel Sousaa, Pedro Arezes ${ }^{\mathrm{a}}$, Diana Mesquita ${ }^{\mathrm{b}}$ \\ aUniversity of Minho, Centro Algoritmi, Production and Systems Engineering, Guimarães, Portugal \\ bUniversity of Minho, Research Centre on Child Studies, Braga, Portugal \\ *rml@dps.uminho.pt
}

\begin{abstract}
The development of projects in industrial context constitutes an exceptional opportunity for engineering students to develop competences expected by the labour market. Therefore, the adoption of this type of interaction within engineering curricula is highly recommended, not only at the end of the degree, but also in the previous years. The main purpose of this paper is to present and analyse a Project-Based learning (PBL) semester in which six teams of Industrial Engineering and Management (IEM) students integrate different areas of knowledge, while solving real problems of five companies, emphasizing the technical solutions developed by the students and the feedback provided by the companies. Students' feedback will be also addressed. The main outcomes of this study reveal that most of the technical solutions lie in areas of Lean applications and ergonomic improvement of workplaces. Companies were very pleased with the results of this type of University-Business Cooperation (UBC).
\end{abstract}

Keywords

Project-based learning. Engineering education. Industrial Engineering and Management. University-Business Cooperation.

How to cite this article: Lima, R. M., Dinis-Carvalho, J., Sousa, R. M., Arezes, P., \& Mesquita, D. (2017). Development of competences while solving real industrial interdisciplinary problems: a successful cooperation with industry. Production, 27(spe), e20162300. http://dx.doi.org/10.1590/0103-6513.230016

\section{Introduction}

Industrial Engineering and Management (IEM) professionals need to solve interdisciplinary problems, mobilizing knowledge from different areas of knowledge, like production planning and control and ergonomics, and resources that are transferable between different professions and functions, like teamwork and leadership. The mobilization of resources, like knowledge, abilities and values, to solve specific professional problems is an evidence of the use of competences (Le Boterf, 1997). Competences related to specific technical areas of IEM are referred in this work as technical competences. Competences that can be transferred between different professional areas and functions will be referred in this work as transversal competences. The professional practice implies the combination of both (technical and transversal) in order to solve engineering problems. A study from Lima et al. (2013) showed that job advertisements for IEM professionals have much more inputs for transversal competences than for technical competences or areas of professional practice. The need for developing transversal competences is reinforced by engineering accreditation bodies (ABET, 2013; Institute for Higher Education Policy, 2008) and several IEM profile studies (Institute of Industrial Engineers, 2012; Mesquita et al., 2015). A previous work showed that the majority of the courses of an IEM degree do not formally specify what transversal competences can be developed in each course (Mesquita et al., 2015). Furthermore, in the comparison of several European IEM curricula, it is not clear that students can interact with companies during their initial training phase (Lima et al., 2012). 
The integrated development of technical and transversal competences aligned with the profession can be seen as a requirement for developing adequate academic curricula for the initial training of engineers. In the perspective of The European Union initiative, University-Business Cooperation (UBC) (European Commission, 2007), "Universities must also provide knowledge and skills geared to the needs of the labor market. In other words, graduates' qualifications must meet the needs of the labor market”. In this context, the creation of opportunities for students to interact with industrial companies can be seen as a way to contribute for developing those competences. This interaction can be promoted through visits to industries, seminars from professionals, internships, direct contact between students and professionals or with projects developed by students for solving real industrial/business problems. The direct integration of curricular opportunities for the development of projects in interaction with companies is classified by Zabalza (2011) as practicum. The engineering report from UNESCO (United Nations Educational, Scientific and Cultural Organization, 2010) reinforced the need for changing the pedagogical methodologies and apply active learning methodologies, peer instruction, problem and project-based learning. Project-based learning (PBL) is one innovative pedagogic approach that can be applied for developing curriculum with practicum opportunities, exploring the need of interaction with the industrial practice. In this work, project-based learning is focused on the development of a project in a real professional context, in which teams of students solve an interdisciplinary problem, articulating theory and practice during the development of a project (Graaff \& Kolmos, 2007; Powell \& Weenk, 2003).

The authors have been developing and studying projects in interaction with industries, in continuous efforts to address the main issues that students, teachers and professionals must address in order to create successful projects (Lima et al., 2015; Lima et al., 2014; Soares et al., 2013). Despite these previous works, and after analysing a set of works published by several researchers (see the section below), there is still the need to study the way these projects are developed, in order to define the technical approaches that facilitate an interaction with industries, that intentionally create benefits for students' learning and for the companies. Furthermore, there is a lack of studies in Industrial Engineering and Management showing the importance of developing competences in learning environments in interaction with professional environments. As a contribution for reducing this knowledge gap, this paper aims to describe projects developed in industry by students in the $4^{\text {th }}$ year of a 5 -year engineering degree $\left(7^{\text {th }}\right.$ semester) and evaluate those projects based on the technical solutions achieved and on the perspectives of the professionals and students.

\section{Analysing learning projects in interaction with industry}

An analysis of cases of learning projects in interaction with industry was developed aiming to create a better perspective of: (1) what can be done in different contexts of Industrial Engineering and Management education that create opportunities for development of projects in interaction with companies; (2) identify and classify different dimensions and variables of these PBL cases. In order to fulfil these objectives a systematic review was developed in 18 October 2016 using the Scopus online database system, which present itself as being “[...] the largest abstract and citation database of peer-reviewed literature: scientific journals, books and conference proceedings" (Elsevier, 2016). Using this research service three consecutive searches were executed, as represented in Table 1. The first search included looked for all documents of engineering education related to problem and project-based learning, and additionally include the term industry, business or company. This was the starting point to identify a large set of references related to the theme of this article.

The step 1 of the search procedure returned documents from all engineering fields. In order to cope with the objective of this paper a second step allowed to restrict the earlier results to include studies only related to Industrial Engineering and Management area. Finally, a third step aiming to increase the quality of results restricted the documents to journals' articles.

Table 1. Search terms and steps.

\begin{tabular}{|c|c|c|c|}
\hline Step & Fields & Terms & results \\
\hline 1 & $\begin{array}{l}\text { Title }+ \\
\text { abstract }+ \\
\text { keywords }\end{array}$ & $\begin{array}{l}\text { "engineering education" AND } \\
\text { (“problem-based learning” OR “project-based learning”) AND } \\
\text { (industry OR business OR company) } \\
\text { AND }\end{array}$ & 380 \\
\hline 2 & All fields & $\begin{array}{l}\text { "industrial engineering" OR "industrial engineering and management" OR "industrial management and } \\
\text { engineering" OR "production engineering" OR "manufacturing engineering" OR "engineering management" } \\
\text { AND }\end{array}$ & 53 \\
\hline 3 & Source Type & Limit to journals & 15 \\
\hline
\end{tabular}


Despite that the search results of step 1 included documents from all engineering fields there was the intention to analyse the five most cited documents of this set. These results were coded with a sequential number preceded by 1 , from 1.1 to 1.5 . These results are presented in Table 2 . The results from step 3 were coded with a sequential number starting with 3 , and chronologically ordered. These results are presented in Table 3. It must be noted that the three most cited references are also included in the set of results of step 3 and for that reason they appear respectively in references 3.08, 3.06 and 3.09. The number of citations for the whole set of references were included, but for this second group they were not considered for the process of analysis.

Table 2. List of the five most cited references.

\begin{tabular}{|c|c|c|c|c|c|}
\hline Code & Reference - Country & Citations & $\begin{array}{c}\text { Program (or department) / } \\
\text { Course (or subject area) }\end{array}$ & Organization & Industrial interaction \\
\hline $\begin{array}{l}1.01 \\
3.08\end{array}$ & $\begin{array}{l}\text { (Bellmunt et al., 2006) } \\
\text { - Spain }\end{array}$ & 61 & $\begin{array}{l}\text { Electrical Engineering / } \\
\text { Electrical Workshop of } \\
\text { Automation }\end{array}$ & $\begin{array}{l}\text { Project-Based Learning course } \\
\qquad 3^{\text {rd }} \text { or } 4^{\text {th }} \text { year } \\
\text { Case study of } 25 \text { students } \\
\text { Time organized in } 8 \text { specific } \\
\text { and consecutive sessions } \\
\text { Prerequisites of knowledge }\end{array}$ & $\begin{array}{c}\text { Automation of a specific } \\
\text { flexible cell with commercial } \\
\text { programmable logic controllers } \\
\text { (PLCs) } \\
\text { Local and remote labs }\end{array}$ \\
\hline $\begin{array}{l}1.02 \\
3.06\end{array}$ & $\begin{array}{c}\text { (Deshpande \& Huang, } \\
\text { 2011) - USA }\end{array}$ & 41 & \multicolumn{3}{|c|}{ Not related to Problem or Project-Based Learning } \\
\hline $\begin{array}{l}1.03 \\
3.09\end{array}$ & $\begin{array}{c}\text { (Chinowsky et al., 2006) } \\
\text { - USA }\end{array}$ & 33 & $\begin{array}{l}\text { Civil, Environmental, and } \\
\text { Architectural Engineering } \\
\text { School; Construction } \\
\text { Engineering and Management }\end{array}$ & $\begin{array}{l}4 \text { Project-Based Learning cases } \\
\text { Mixing graduate and under } \\
\text { graduate students } \\
\text { Case } 1 \text { to case } 4 \text { number of } \\
\text { students: } 6,6,5 \text { and } 14 \text {. } \\
\text { Time organized in } 5 \text { phases }\end{array}$ & $\begin{array}{l}\text { Periodic meetings with staff, } \\
\text { professionals and contractor. } \\
\text { Real problems with real } \\
\text { customers. } \\
\text { Students play the role of } \\
\text { construction managers. }\end{array}$ \\
\hline 1.04 & $\begin{array}{l}\text { (Crosthwaite et al., 2006) } \\
\text { - Australia }\end{array}$ & 26 & $\begin{array}{l}\text { Chemical Engineering / } \\
\text { Project Centred Curriculum } \\
\text { (PCC) (Several courses in the } \\
\text { curriculum) }\end{array}$ & $\begin{array}{c}\text { Project-Based learning model } \\
\text { One project by semester } \\
\text { 4-6 students per group } \\
\text { 6-13 weeks duration } \\
10 \text { years of experience }\end{array}$ & $\begin{array}{l}\text { Simulation of professional } \\
\text { practice scenarios sourced from } \\
\text { industry and research }\end{array}$ \\
\hline 1.05 & $\begin{array}{l}\text { (Massey et al., 2006) } \\
\text { - USA }\end{array}$ & 26 & $\begin{array}{c}\text { Business School, School of } \\
\text { Informatics, Computer } \\
\text { Science Department, and } \\
\text { Telecommunications Department } \\
\text { / Mobile Applications } \\
\text { Development (MAD) }\end{array}$ & $\begin{array}{l}3 \text { Project-Based Learning cases } \\
\text { Students of each masters' } \\
\text { program case: } 28,16 \text { and } 16 . \\
\text { Groups with students with } \\
\text { different backgrounds } \\
16 \text { week project }\end{array}$ & $\begin{array}{l}\text { Industry sponsor competition } \\
\text { for each PBL case. } \\
\text { University based project in } \\
\text { interaction with industry } \\
\text { sponsors }\end{array}$ \\
\hline
\end{tabular}

Table 3. List of references related to Industrial Engineering and Management areas.

\begin{tabular}{|c|c|c|c|c|c|}
\hline Code & $\begin{array}{l}\text { Reference - } \\
\text { Country }\end{array}$ & Citations & $\begin{array}{l}\text { Program / Course } \\
\text { (or subject area) }\end{array}$ & Organization & Industrial interaction \\
\hline 3.01 & $\begin{array}{l}\text { (Chung et al., } \\
\text { 2016) - Taiwan }\end{array}$ & 0 & $\begin{array}{l}\text { Business and } \\
\text { management studies } \\
\text { at a technological } \\
\text { university / Practical } \\
\text { Monograph }\end{array}$ & $\begin{array}{l}\text { Project-Based learning } \\
51 \text { students } \\
14 \text { groups } \\
\text { 3-4 students per group } \\
11 \text { weeks }\end{array}$ & $\begin{array}{l}\text { Integrate theory and on-site visits. } \\
\text { Number of visits, process and projects } \\
\text { are not clear. }\end{array}$ \\
\hline 3.02 & $\begin{array}{l}\text { (Kim, 2015) - } \\
\text { Korea }\end{array}$ & 1 & $\begin{array}{l}\text { Industrial Engineering / } \\
\text { Capstone Course }\end{array}$ & $\begin{array}{l}\text { Capstone project } \\
3-5 \text { students per group } \\
15 \text { weeks in } 7^{\text {th }} \text { semester } \\
\text { Pre-course for team formation, project } \\
\text { definition / selection. } \\
\text { Class-course for the project } \\
\text { Post-course for writing a proposal or } \\
\text { submitting papers }\end{array}$ & $\begin{array}{l}\text { The projects can be formulated by } \\
\text { students based on industrial problems, } \\
\text { can be based on faculty projects, } \\
\text { proposed by the engineering school or } \\
\text { to enter in competitions } \\
\text { Communication with industrial clients }\end{array}$ \\
\hline 3.03 & $\begin{array}{l}\text { (Pomales-García } \\
\text { \& Barreto, 2014) } \\
\text { - Puerto Rico }\end{array}$ & 7 & $\begin{array}{l}\text { lndustrial Engineering / } \\
\text { Work Design and Work } \\
\text { Measurement }\end{array}$ & $\begin{array}{l}2 \text { design courses with } 3 \text { different } \\
\text { Project-Based Learning approaches: } \\
\text { case study, service industry and } \\
\text { manufacturing industry } \\
161 \text { students } \\
\text { Group formation not stated } \\
4^{\text {th }} \text { year (out of 5) } \\
5 \text { years' analysis of projects }\end{array}$ & Several visits in some of the cases \\
\hline 3.04 & $\begin{array}{l}\text { (Kanigolla et al., } \\
\text { 2014) - USA }\end{array}$ & 0 & $\begin{array}{l}\text { Engineering } \\
\text { Management and } \\
\text { Systems Engineering } \\
\text { Department / Lean and } \\
\text { Six Sigma engineering } \\
\text { courses }\end{array}$ & $\begin{array}{l}\text { Two graduate level Project-Based } \\
\text { Learning courses } \\
26 \text { students from the Lean course } \\
\text { and } 54 \text { students from the Six Sigma } \\
\text { participated in the study } \\
\text { 3-4 students per group } \\
\text { One semester projects }\end{array}$ & $\begin{array}{l}\text { Projects based on real problems from } \\
\text { local companies } \\
\text { lntensity of interaction is not } \\
\text { described }\end{array}$ \\
\hline
\end{tabular}


Table 3. Continued...

\begin{tabular}{|c|c|c|c|c|c|}
\hline Code & $\begin{array}{l}\text { Reference - } \\
\text { Country }\end{array}$ & Citations & $\begin{array}{l}\text { Program / Course } \\
\text { (or subject area) }\end{array}$ & Organization & Industrial interaction \\
\hline 3.05 & $\begin{array}{l}\text { (Kanigolla et al., } \\
\text { 2013) - USA }\end{array}$ & 3 & $\begin{array}{l}\text { Engineering } \\
\text { Management and } \\
\text { Systems Engineering } \\
\text { Department / Quality } \\
\text { and Six Sigma } \\
\text { engineering courses }\end{array}$ & $\begin{array}{l}\text { Two Project-Based learning courses } \\
\text { Quality - undergraduate level } \\
\text { Six Sigma - graduate level } \\
34 \text { students from the Quality course } \\
\text { and } 54 \text { students from the Six Sigma } \\
\text { participated in the study } \\
\text { 3-4 students per group } \\
\text { One semester projects }\end{array}$ & $\begin{array}{l}\text { Projects based on a real-world process } \\
\text { improvement project from local } \\
\text { companies } \\
\text { Intensity of interaction is not } \\
\text { described }\end{array}$ \\
\hline 3.06 & $\begin{array}{l}\text { (Deshpande \& } \\
\text { Huang, 2011) } \\
\text { - USA } \\
\end{array}$ & 41 & \multicolumn{3}{|c|}{ Not related to Problem or Project-Based Learning } \\
\hline 3.07 & $\begin{array}{l}\text { (Lau et al., 2006) } \\
\text { - Hong Kong }\end{array}$ & 11 & $\begin{array}{l}\text { Industrial Engineering / } \\
\text { courses not referred }\end{array}$ & $\begin{array}{l}\text { Virtual system with cases for Problem- } \\
\text { Based Learning } \\
\text { Reference to developments in several } \\
\text { subjects (not specified) } \\
\text { Organization of students or time are } \\
\text { not referred }\end{array}$ & $\begin{array}{l}\text { Virtual company problems } \\
\text { Scenarios composed of case problems } \\
\text { with videos }\end{array}$ \\
\hline 3.08 & $\begin{array}{l}\text { (Bellmunt et al., } \\
\text { 2006) - Spain }\end{array}$ & 61 & See 1.01 at Table 2 & & \\
\hline 3.09 & $\begin{array}{l}\text { (Chinowsky et al., } \\
\text { 2006) - USA }\end{array}$ & 33 & See 1.03 at Table 2 & & \\
\hline 3.10 & $\begin{array}{l}\text { (Paten et al., } \\
\text { 2005) - USA }\end{array}$ & 17 & \multicolumn{3}{|c|}{ Not related to Problem or Project-Based Learning } \\
\hline 3.11 & $\begin{array}{l}\text { (Lau \& Mak, } \\
\text { 2005) - Hong } \\
\text { Kong }\end{array}$ & 8 & See 3.07 & & \\
\hline 3.12 & $\begin{array}{l}\text { (Lau \& Mak, } \\
\text { 2004) - Hong } \\
\text { Kong }\end{array}$ & 10 & See 3.07 & & Reference to "realistic case problems" \\
\hline 3.13 & $\begin{array}{l}\text { (Xu \& Duhovic, } \\
\text { 2004) - New } \\
\text { Zealand }\end{array}$ & 8 & $\begin{array}{l}\text { Engineering program / } \\
\text { Manufacturing Systems }\end{array}$ & $\begin{array}{l}\text { Project-based learning based on a case } \\
\text { study and an assignment approach } \\
\text { Third year, second semester } \\
\text { A seventh of the total semester credits } \\
\text { Number of students per group is not } \\
\text { stated }\end{array}$ & $\begin{array}{l}\text { Industry based case study } \\
\text { Simulation of industrial common } \\
\text { practices } \\
\text { Computer integrated manufacturing } \\
\text { scenario } \\
\text { One visit to the company }\end{array}$ \\
\hline 3.14 & $\begin{array}{l}\text { (McCarthy et al., } \\
\text { 2004) - New } \\
\text { Zealand }\end{array}$ & 3 & $\begin{array}{l}\text { Mechanical Engineering } \\
\text { / Manufacturing } \\
\text { Systems }\end{array}$ & $\begin{array}{l}\text { Project-based learning approach } \\
\text { Fourth year course } \\
\text { Apparently around } 100 \text { students } \\
\text { Organization of students or time are } \\
\text { not referred }\end{array}$ & $\begin{array}{l}\text { Immersive ergonomics project in a } \\
\text { prototype virtual factory. } \\
\text { The Project scenario is based on a } \\
\text { real process from industry where } \\
\text { an operator performs repetitive } \\
\text { operations. } \\
\text { Application of previous courses' } \\
\text { concepts }\end{array}$ \\
\hline 3.15 & $\begin{array}{l}\text { (Hung et al., } \\
\text { 2003) - Hong } \\
\text { Kong }\end{array}$ & 11 & $\begin{array}{l}\text { Mechanical and } \\
\text { manufacturing } \\
\text { engineering / course } \\
\text { not referred }\end{array}$ & $\begin{array}{l}\text { Project-Based Learning approach } \\
\text { Five students per group } \\
\text { Integrate various subject areas studied } \\
\text { in the program }\end{array}$ & $\begin{array}{l}\text { Simulation of a real manufacturing } \\
\text { problem }\end{array}$ \\
\hline
\end{tabular}

In the first phase of analysis, all abstracts were read and the references were classified in relation to the country and the program they were related to. In this phase, two papers were disregarded because they were considered as not related to Project-Based learning. In the second phase all documents were read and a deeper analysis was developed centred on the following criteria: Course, Organization and Industrial interaction. A summary of the results are described in both Tables 2 and 3.

As referred above, in the set of works included in Table 2 there are three works related to the Industrial Engineering and Management area of knowledge. This interesting result shows that some of the most important works of PBL in interaction with industry is developed in Industrial Engineering and Management programs.

The foundation of most of the papers included in this review is the need to align the curriculum with the development of professional competences. In this context, Crosthwaite et al. (2006) describe a pedagogical model with five main processes applied in a never-ended cycle, and named as follows: Graduate Attributes; Learning Objectives; Learning Activities; Assessment Tasks; Assessment Criteria \& Standards. These processes demonstrate the importance of identification of the professional competences' requirements. The identification of professional competences is reinforced in some works (Chung et al., 2016; Lima et al., 2012; Mesquita et al., 2015). 
A reason for the development of PBL environments is the development of competences, and not sole the acquisition and assessment of knowledge. Competences are also a central aspect of this work and for that reason was defined at the beginning of the introduction. However, this concept has not a unanimous understanding among the research community, neither in definition nor in classes of competences considered. In this line of thought, Crosthwaite et al. (2006, p. 42) consider the meta classes technical and generic, and use the term graduate attributes classified in four classes:

(1) foundation skills which are expected and separated from discipline skills; (2) personal skills which are considered important, but are still separate and independent of discipline; (3) clusters of personal attributes, knowledge and skills separate from, but enabling the application of and not seen as independent of discipline knowledge; and (4) abilities essential to and integrated with discipline knowledge and learning.

In another study, by Chung et al. (2016), there is a set of sixteen industrial-oriented competences, classified in three classes as generic (e.g. Communication), professional (e.g. Accounting and statistical analysis) and workforce (e.g. Team work). Despite the fact that these competences are not defined in detail, a generic interpretation of the terms used in both the generic and the workforce, would make it possible to classify them as transversal in the classification used in this work. In general, the perspective used for attributes and competences of the works analysed are aligned with the definition of competence used in this work.

The number of articles that relate PBL with industry aspects is scarce, and in this research a total number of 13 were identified as relevant and analysed. Certainly, a higher number of works are being developed, but are not being published. This creates the need to increase the number of publications in this area, in order to answer to what is being done in different parts of the world and with what results, and understand and adapt how it can be done. In the screening presented here, most of the cases referred to group work and to the development of some sort of project. Regarding the industrial interaction (either manufacturing or service) in project approaches, it was possible to create the following classification:

- Simulation: problems presented to students are based on real problems, in what can be described as realistic problems, presented most of the times as case studies. The projects described in papers 3.07, 08, 11, 12, 13, 14, and 15 , can be included in this classification.

- Visits: some of the projects' courses include visits to companies to clarify problems or grasp the real world context. The projects described in papers 3.01, 03 and 13 refer one to several visits to companies.

- Industry: a few projects describe projects to solve real problems in interaction with companies or contractors. Despite this, it is not clear the intensity of that interaction. Projects described in papers 3.02, 04, 05, and 09, can be included in this classification.

This systematic review presents a starting point for this and other works that intends to explore the introduction of real problems in Project-Based learning approaches in Industrial Engineering and Management programs.

\section{PBL context}

The PBL edition analysed in this work involves six teams of students from the $7^{\text {th }}$ semester of the lntegrated Master Course on Industrial Engineering and Management (IEM) and it is formalized in the curricular structure through the Integrated Project on Industrial Engineering and Management 11 course (IPIEM 11). The other courses of the semester, (i) Production Systems Organization 11 (OSP 11), (ii) Production Information Systems (SIP), (iii) Simulation (SIM), (iv) Ergonomic Studies for Workstations (EEPT) and (v) Production Integrated Management (GIP) are project-supporting courses (Figure 1). This project has a specific curricular integration, in which students are expected to develop competences from the previously referred courses and integrate them during the process. This means that a specific type of project and openness are required from the companies, which accept to receive the students at least weekly in order to create the opportunities for teams to develop the project with such a broad spectrum. Nevertheless, students in accordance with teachers and the company can focus in specific problems short time after the mid of semester.

Comparing this project with the examples that were researched in this work, it was possible to identify two unique characteristics of this one:

- Integration of courses: there was any other project in interaction with the industry showing such a high level of integration between different courses. 


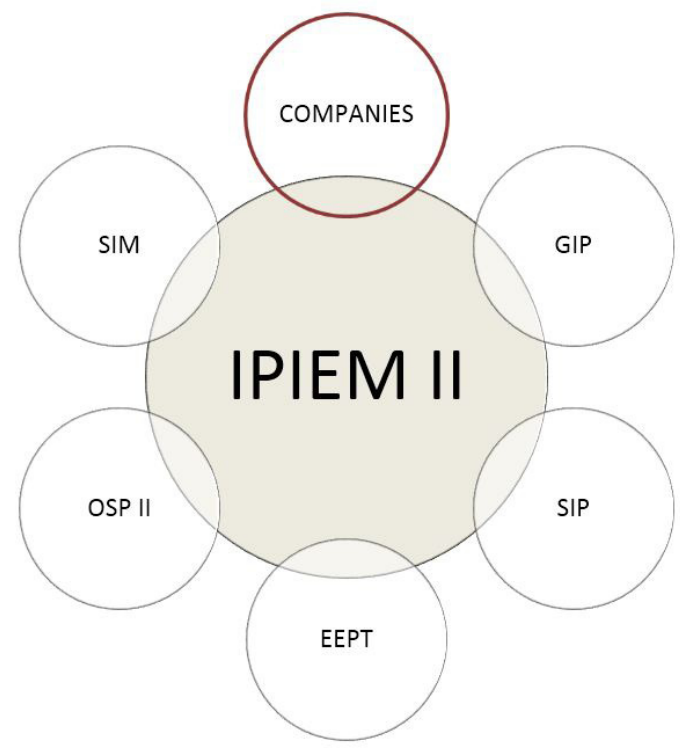

Figure 1. lllustration of the interdisciplinary relation between different project supporting courses and the companies.

- Intensity of interaction: another unique characteristic that was identified in this project is the high level of intensity of interaction. Students have the opportunity to work in the company facilities at least one day per week.

Each team of students team is associated with a company (six companies are involved) and, in general terms, the main stages of the project are: (i) exploration, (ii) analysis and diagnosis of the company's production system and (iii) development of improvement proposals (Figure 2). During the exploration phase, students are assigned to teams and projects in a process mostly influenced by their will. After that, the first visits are made, and the teams start establishing their communication process with the company and their agents, understanding the company production system in a generic way, and finally defining the specific objectives of the project. In the second stage, and in the context of each one of five project supporting courses, students' teams use different representation and analysis methodologies/tools to evaluate the production system and identify problems. In the third stage, the teams should develop improvement proposals, using the different intervention tools/methodologies provided by the project supporting courses, in order to deal with at least one of the identified problems. In this particular IPIEM 11 edition, developed from mid September 2015 to mid January 2016, the main proposals were developed in the areas of Lean Manufacturing and Ergonomics. In fact, contrarily to the first stage, where all the supporting courses' subjects should be properly addressed, in the improvement proposals' stage a single theme might be considered if, obviously, both the inherent workload and relevance for the company are adequate.

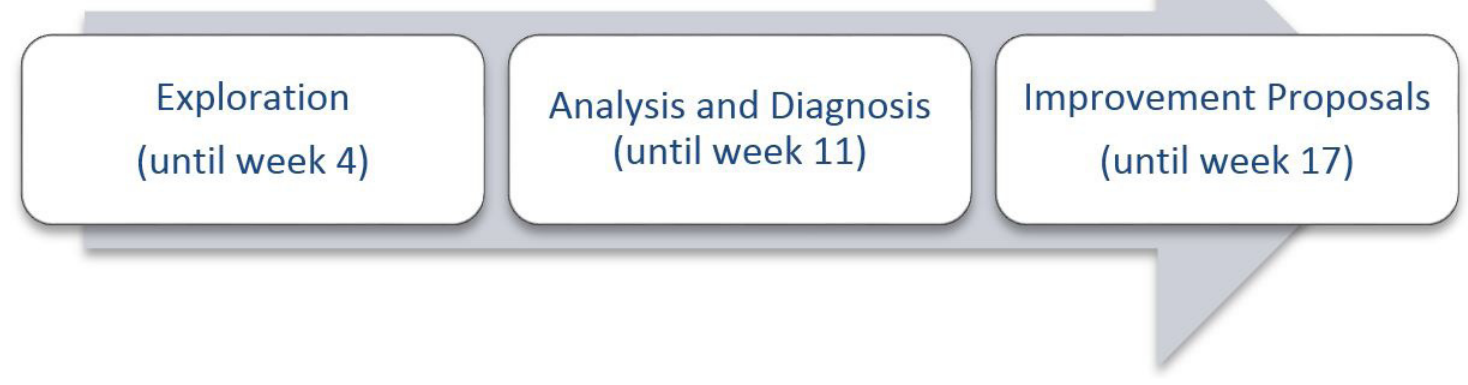

Figure 2. Phases of the project. 
During the whole semester, the project is supervised by a coordination team composed by the teachers of the project supporting courses, the team's tutors and the researchers that provide pedagogic support to IPIEM 11. Furthermore, professionals from the six companies involved in this edition also support the project (company tutors). The companies are from several types of industry: (Company $\mathrm{C}$ ) textile yarn and fabrics for the automotive industry, (L) electrical wiring for industrial machinery, (V) electrical capacitors (I) furniture, (S) files and handsaws, and (R) plastic films for packing. In brief terms, the main production processes involved are: company $\mathrm{C}$ - winding (yarn), weaving (fabrics) and finishing; company $\mathrm{L}$ - cutting (wires), interlacing (cables), and welding/crimping (connectors/terminals); company $\mathrm{V}$ - winding (insulators and conductors) encapsulation and welding (terminals). Companies 1 and $\mathrm{S}$ involve the typical processes of wooden furniture and metal mechanic industries, respectively. Finally, in company R, the main process is the extrusion of the plastic film.

\section{Research methodology}

A qualitative approach was used in this study, in order to get an in-deep understanding on how university and industry can cooperate in a context of PBL. In this sense, technical solutions developed by students were analysed and an overview about the process (e.g. benefits, constraints, suggestions) was carried out, considering the perceptions of companies' representatives and of students involved.

In short, the methodological approach considered in this work is based on two main activities.

First, in order to describe the technical solutions developed by students' teams, a document analysis was carried out based on project reports and blogs (the two main deliverables of each team of students). This analysis permits to identify the main technical contributions of the projects, both for the development of the expected competences and for the improvements and innovation expected by companies.

Second, an evaluation of the process was carried out at the end of the project using two different approaches: (i) Five semi-structure interviews were conducted with professionals from five different companies (recorded and transcribed verbatim). The main topics discussed were positive results for the company, difficulties of the process and suggestions to be implemented in further projects; (ii) Students' perspectives were also considered, taking into account a questionnaire carried out at the end of the project $(n=25)$ in which they could identify the positive and less positive aspects of the process, as well as suggestions of improvement.

The analysis of the data collected will be presented in the following sections.

\section{Technical solutions developed by students}

The technical solutions proposed by the students were focused in very different aspects of companies and their workplaces. All the solutions were based in previous diagnostic of the corresponding production systems.

Allowing to establish a link between the type of solution and the involved companies, the reference of each case is composed by the first letter of the company's name. Other details of the proposed solutions are not presented in the current paper due to obvious space limitations.

Due to the broad nature of the proposed solutions, these are presented in the following sections according to a classification into different domains.

\subsection{Physical environment improvements}

Almost all the workplaces have some type of potential improvement in what regards physical environments, as most of them are far from what it is considered to be the most comfortable setting or the ideal physical environment. However, during the diagnosis phases, two major problems were identified by the groups: i) in the company $\mathrm{R}$ it were identified low levels of lighting in visual demanding workplaces, which are more critic as the need of accurate vision is higher than in other analysed workplaces. The technical proposed solution was to increase the number of lamps and its power, taking into consideration that there was a need to ensure a uniform light intensity distribution along the workplace areas of about 300 lux; ii) in the company $V$ some workplaces were identified as being exposed to sound pressure levels higher than the maximum threshold defined in the legislation. The technical proposed solution was, in this case, to implement a physical encapsulation of the feed area of the machine.

The identified impact of the proposed solutions for both solutions are, respectively, an increase of lighting levels, with the consequent increase of workers' well-being and a reduction of visual problems, which may also lead to a lower probability to make errors and an improved product quality. The second solution will imply a lower noise exposure and the preservation of the workers' hearing levels. 


\subsection{Manual materials handling and critical postures}

Industrial activities, such as the one that were analysed thorough the majority of the workplaces, have some transportation activities (materials, tools, finished products) between different locations in the company. Some of these transportation activities imply high-risk situations, namely in what concerns the risk of work-related musculoskeletal disorders (WRMSDs).

In company R, some of these high-risk activities have been identified and the proposed solution was the adoption of mechanical aid, consisting of a mechanical crane with a pressure application pinch that can be used to lift and lower heavy loads. With such a decrease of the manual handling, as well as the decrease of the loads in some activities, a decrease in the overall risk is expected as it was demonstrated by the computations presented with a risk assessment method. This will have, hopefully, a significant impact on the absenteeism and/or in reported pain or discomfort by involved workers

In company $\mathrm{S}$, the problem was not related to the loads but with the frequency of the load handling in very low shelves. The proposed technical solution was to redesign the transport trolley, with a new design and placement of the shelves. The trolley was completely redesigned and shelves can now be moved through the use of a pedal. A significant reduction on the adoption of critical postures was obtained, as demonstrated by the results of the application of a posture risk assessment tool.

Finally, in the company $\mathrm{V}$, excessive load activities were also found when handling the finished product boxes. For this, a redesign of a plastic box with lower capacity and handles was proposed, which will reduce the handling activities and minimize the risk of WMSDs.

\subsection{Accident prevention}

Accident prevention is always a major issue when it comes to risk analysis and control at industrial companies. The idea here was to identify those situations that are more prone to originate a high risk of accident and propose mitigation measures. For example, in company $\mathrm{L}$, a possible fall out of the reels when they are being used at the warehouse shelves was identified as being a major accident risk situation. For this, it was proposed that reels can be protected by a barrier mechanism that can be easily opened when a specific reel is being used. The solution included the creation of a "two-arms" barrier that can be easily opened. This will prevent the falloff the reel with the corresponding elimination of its consequences.

In company $\mathrm{C}$, the major risk was the handling of the fabric rolls and the transport to the expedition truck, which is done manually and with a fork-lift truck and it represents a clear accident risk factor. Several measures can be adopted and were proposed, one consisted in including the handling of the rolls based on a mechanical "arm". Additionally, it was also proposed that the rolls' palette should be specifically designed to avoid the movement of the rolls, allowing a more flexible handling of the fabric rolls. This solution will have a high impact on the reduction of handling load for the operator but the corresponding costs are high for the company.

\subsection{OEE monitoring \& improvement}

Overall Equipment Effectiveness (OEE) is a performance indicator designed to measure the utilization of critical equipment in three different dimensions, Availability, Performance and Quality (Hansen, 2001). In two companies, this indicator was addressed in the student's project in two different ways. In company R1 this indicator did not exist since they did not have any recording practices. The team had to create printed forms for the operator to record OEE related data. Additionally, the team created Excel sheets to store, compute and display results. The worksheet developed computes data and creates reports and important graphs to show visually information to managers and workers. In a very short period of time a better knowledge of machine utilization was achieved leading rapidly to productivity improvements.

In company L, OEE monitoring was already a reality for several years, but its value was a very low 0EE (27\%) in a specific set of machines. This low OEE was due to the high number of setups taking place in order to keep low inventories. Students applied the technique known as SMED (Single Minute Exchange of Die) (Shingo, 1985) to reduce the machine changeover. Students end up creating new setup standards with small changes in the machines to allow parallel setup operations with one more operator in the setup. These changes resulted in a reduction of setup time from 11 minutes to 6 minutes in average. 


\subsection{Cell layout and flow improvement}

A very common characteristic of non-lean practices in production is poor layouts with a very complex network of material's routes, high levels of transport and motion waste and WIP everywhere in the shop floor. Companies $\mathrm{R}$ and $\mathrm{L}$ are very good examples of companies with these practices. These practices are very commonly found in production systems organized in process based approaches with little concern on flow, which is one of the key principles of Lean Manufacturing. In company R students designed a new layout more flow oriented with less transport and motion waste. Machines were moved to better locations and some machines were also changed to separate loading from unloading. The changes in layout resulted in better access to load and unload materials with less transport and motion waste; more utilization of worker in value adding activities since non-adding value operations were removed; better material flows with less WIP; and higher productivity.

Company $\mathrm{L}$ although with similar problems reported for company $\mathrm{R}$, had also problems related to unbalance workstation capacity. Students also developed a new layout, moving machines to new locations according to the main flow of materials. Workstations were also balanced and the batch size was reduced in order to improve flow. The results achieved were basically a $77 \%$ reduction in transport distances, as well as a throughput time reduction of $50 \%$.

\subsection{Internal logistics}

Internal logistics is an important issue in most companies, but especially in companies with a focus on assembly operations. Transporting components from warehouses to assembly lines or cells does not add value to products but uses a quite large amount of resources in companies. Large amounts of inventory of components in different shop floor locations, a lot of handling, and parts missing in the assembly area, are examples of typical problems found in this type of production. Company $\mathrm{C}$ was diagnosed by students to have high levels of WIP, lack of flow, and communication problems. Students designed and implemented a pull system to manage the flow of materials from the warehouse to the assembly area and also designed and implemented a new layout of the material warehouse in order to minimise distances to be travelled by workers. With these improvements, students reached a 50\% reduction of WIP and throughput time of materials on the shop floor.

Company $\mathrm{S}$ had a more organized internal logistic system with a mizusumashi to deliver materials to the assembly areas. The main problem identified by students with this system was the high variability of routes taken by the mizusumashi as well as the route time's unpredictability. Students proposed a new layout to the existing supermarkets and created new standards for the mizusumashi routes as well as new standard to the mizusumashi operations. The implementation of these new standards and new layouts led to a 30\% reduction on the time spend in the supermarket and 20\% less time in the mizusumashi routes.

\subsection{Cell balancing and setup reduction}

Cell and line balancing is a classic issue in production studies and its complexity increases as the mix of products to be assembled in the cell or line also increase. In the presence of relevant machine changeover needs the problem becomes even more complicated. Company $\mathrm{V}$ was an example of all these issues in an assembly cell. In the assembly cell analysed by students, products need to go several times through stoves for several hours and some machinery need changeovers every time a new product had to be assembled. Large amounts of WIP were a reality in the cell, the cell was very unbalanced, setup times were high and low productivity was recognized with many types of production waste in the cell. A new layout was proposed and implemented by the team of students as well as new allocation of operations to workstations in order to better balance the cell and improve its efficiency. With this new cell design, the number of workers needed to operate the cell was reduced from 7 to 5 and the lead time was reduced in 68\%. The team also applied the SMED technique to reduce the setup time in a critical machine achieving a reduction from 87 to 29 minutes.

\section{Process evaluation}

For the purpose of evaluating the process in terms of the projects developed, professionals and students' perspectives were considered. The data analysis point out two main ideas: (1) PBL as an added-value for students learning; (2) Benefits for companies; (3) Constraints and recommendations for practice. 


\subsection{PBL as an added-value for students learning}

Several studies highlight the importance of PBL for students' learning, in terms of engagement, motivation, develop competences related to professional practice, amongst other issues (Fernandes et al., 2014; Kolmos \& Holgaard, 2010; lima et al., 2007). When PBL is developed in real contexts, like a company, students have the opportunity to develop technical competences but their learning experience go further because they start to feel what is like being an industrial engineer: solve different problems (production and planning, organization, logistics, ergonomics), communicate to the CEO of the company, get information, observing and analysing the system, interact with operators, trying to implement changes, etc. In other words, the students have the opportunity to practice the professional practice.

The data collected in the context of this study reinforce this statement. From students' point of view the added-value of PBL is to use the content from different courses in real and complex industrial environments. The most positive aspect of PBL, for one of the students that responded to the questionnaire is: "to apply the knowledge in ways that 1 will never forget". This shows how PBL have impact on students learning. Moreover, be within an industrial context, dealing with real problems and interacting with professionals are also issues highlighted by the students.

Analysing interviews to the professionals involved in PBL it is possible to reinforce the importance of PBL for students as an opportunity to practice the professional practice, in which they have a real context that create an environment where a deep learning can happen, as it is possible to identify in these examples provided by the companies' representatives:

Basically, these students starts to see a different reality [...] the company, the machines, the operators, to see the people... and I think this is very interesting for them (Company V)

I have to tell you this: I was delighted with these students, with their performance, interest [...] For instance, they had lunch in our canteen and started to be inside of our world. For many people this not a big deal, but for me means a lot, which is the ability they had in integrating with people, in our daily routines. And this happened because of them, because they wanted to! (Company $\mathrm{L}$ )

$I$ realize that they understood our way of work very well, and it is not easy. We've already had several groups of students here and at the end they appear with unrealistic and impractical solutions. But this group came with a very simple and practical approach for the processes and also for the possible solutions. We have had conceptual discussions during the project and they considered that feedback in the proposals... and I think this is a very positive point! They really have been able to create viable solutions and ideas [...] (Company S)

In fact, developing a project in an industrial environment provides learning experiences that go beyond the content applied. Students become more confident for the challenges of professional practice (Mesquita, 2015).

\subsection{Benefits for companies}

If the PBL is an added-value for students learning, what are the benefits for the companies engaged in the process? The win-win approach is an important purpose for an interaction between universities and companies. The sustainability of cooperation depends on that.

In this sense, companies' representatives were asked about what were the main advantages of this type of project, in terms of potential and contributions for the company, that keep them interested to participate over the years. Analysing the data three benefits were identified, namely: (i) technical results; (ii) think outside the box; (iii) recruitment opportunities.

\section{(i) Technical results:}

In the section 4 the technical solutions developed by students were presented in detail. From point of view of the companies' representatives, these results are impressive because the proposals presented by the students are possible put in practice. During the project students go the company once a week (or more) to collect data, they discuss the ideas with several teachers who support them to develop those ideas in order to create coherent and significant proposals, like this one:

We are talking about machines that cost around 250 thousands euros. The setup is crucial. They [students] present results in which we could have gains around 2 minutes. This means going from 4' 75" to 2' 75" in a section here we have 14 cutting machines working in two shifts, making around 500 setups per day... we are talking about more than a 1000 minutes, which means, is one machine! (Company $\mathrm{L}$ ) 
The impact of the proposals presented by the students, sometimes, go further. In this example, the company representative mentioned that the OEE solution (for more details see section 4.4) was so significant that he started developing more ideas to implement. Thus, the project might be also considered a starting point for other changes in industry contexts.

[...] the proposals developed by the team are so viable and real that can be implemented [...] the OEE [Overall Equipment Effectiveness] was one of the main topics that we needed here in the company to develop and the team done more than we've expected! So, for us, the objective was overcome because they got together all information that is relevant and this also help me to get other ideas... layout changes, milk run, for instance (Company R)

(ii) Think outside the box

Another benefit identified by the companies' representatives is the opportunity to get some inputs about the company from the outside, providing a space for creativity and innovation. The proposals developed by students are based on a fresh look about the company system. For them, everything is new, everything is possible. According to one of the professionals:

[...] they can think out of the box and they can pay attention the some situations that for us are invisible, we don't see them at all! Something are simple things, but for us is not so obvious (Company C)

The importance of students visit the company every week, to question about the processes and situations that they are studying, turns visible what for the professionals in the company is invisible.

It is the example of the screens! In that time it was important for the costumer to see that we have a specific area for their products (dedicated assembly line) and it also made sense considering the way that we used to work. But not now! We changed the way has we work but the screens are still there, until the students questioned about it... very well, indeed... because the screens affected the field of vision of the operators! (Company $\mathrm{L}$ )

(iii) Recruitment opportunities:

As aforementioned, this type of projects provides a strong interaction between students and their professional practice. In this context, students have the opportunity to show their competences, a combination between technical and transversal ones. For instance, the professional contexts imply to use knowledge in different ways: explain to an operator the way he/she needs to change the process; explain to the CEO the problems and solutions provided. Thus, the company representatives have the opportunity to know students' profile and this is a long-term benefit for the companies, as mentioned by this professional:

I was doing interviews to recruit four engineers. If these students, who did the project, already had the degree, I would not even to do interview! I wish I could give everyone the opportunity to work here! (Company L)

In fact, some of the companies that are involved in these projects are alumni students. They have also done this project and now are on the other side and, for that reason, recognize the benefit of these projects for both, universities and companies.

\subsection{Constraints and recommendations for practice}

The overall perspective of the companies was positive, but some of them pointed specifically three difficulties, namely (i) Lack of communication between university and company; (ii) To be available to interact with the students; (iii) Workload needed to evaluate and implement solutions proposed by the students. Nevertheless, based on the experience of the teachers involved and the suggestions made by students and companies' representatives a set of recommendations for practice will be also presented, in order to support those who want to implement a PBL approach in interaction with industry.

(i) Lack of communication between university and company

Communication between university and company is essential for the success of cooperation (Healy et al.,). In PBL context, the communication process between teachers and companies' representative starts before the project, by aligning expectations, defining problems to be analysed by students, and to agree on the milestones for the project. During the project, tutors are responsible to follow up their teams in the company. At the end of the project, the coordinator of the project collects feedback from the companies' representatives about the whole process and the team performance. Thus, communication is essential to make the PBL works but is one of the most difficult dimensions in practice, as mentioned by this example: 
The students came here always alone and don't have, in my perspective, a person from the university to support them here. Don't have to be always, but in the first visit, for example, I think is crucial to align expectations and also to know all the people involved. (Company V)

In fact, this is an issue that needs to be improved in the future because students also recognize the communication between university and company as the less positive aspect of PBL.

(ii) To be available to interact with the students

One of the difficulties identified by all companies' representatives that were interviewed is the difficulty to be available to interact with the students every week, because they have other tasks and responsibilities during that day. Thus, it is important to prepare students previously for that.

I am here in the speed of light, always running, always with several things at the same time, lots of meetings and emails... it is hard and 1 cannot stop everything to check what students are doing (Company V)

We've always tried to do a meeting with them in the beginning and at the end of every visit, but not always is possible to give them the support they need for several reasons (Company S)

(iii) Workload needed to evaluate and implement solutions proposed by the students

During the project student analyse and develop proposals for problems identified also by them. Some of the proposals can be implemented immediately and others requires an in-deep analysis from the company, because might affect different departments, for instance. Thus, one of the difficulties identified is the work that is needed to do after the project in order to evaluate the proposals.

I need to recognize that, sometimes, we don't have enough time to be dedicated to analyse the implementation of all the proposals. At this moment, I don't have resources to have an engineer to test and apply the proposals. Some of them were immediate because we've already work one them, but other, need to be in stand by (Company R)

[...] in this moment 1 have interesting data that students delivered me in a report but now 1 have to work as a hell in terms to put that into practice and 1 have to back to the beginning (Company V)

Based on these difficulties a set of recommendations will be presented Table 4 in order to support those who intend to implement PBL in interaction with industry.

Table 4. Recommendations.

\begin{tabular}{|c|c|}
\hline Dimension & Recommendation \\
\hline Communication & $\begin{array}{l}\text { PBL is an open project, so it is important aligning expectations between university and company, not only in } \\
\text { the beginning but reinforcing during the process, in order to guarantee that is clear for all stakeholders what is } \\
\text { expected. } \\
\text { The contact between teachers and the company need to be more frequent during the project. So, it is recommended } \\
\text { using the project milestones as a moment to do an evaluation of the process. This action will contribute for the } \\
\text { previous one. } \\
\text { The companies' representatives must be invited to attend students' presentations. It is a great moment to get } \\
\text { feedback from all stakeholders involved. } \\
\text { Tutors must be able to go to the company, at least, two times: in the first visit and in the end of the project. Mine } \\
\text { while, it is recommended to be aware of students' needs and interact to the company by email, for instance. }\end{array}$ \\
\hline Preparing the students & $\begin{array}{l}\text { Reinforce with the students the importance of the weekly visits, particularly in the beginning of the project in order } \\
\text { to understand how the company works. } \\
\text { Depending on the type of company, students must be aware of their behaviour during the visits (e.g. appropriate } \\
\text { cloths, language). } \\
\text { lt is important to do a final presentation at the company. Students must realize that do a presentation in a } \\
\text { company is different to do a presentation at the university. }\end{array}$ \\
\hline Future work & $\begin{array}{l}\text { In the end of the project, future collaboration must be considered. Open possibilities: to develop the project } \\
\text { proposals, avoiding the workload, come up with a capstone or a final project; discuss briefly the problems that can } \\
\text { be analysed in the next PBL; ... }\end{array}$ \\
\hline
\end{tabular}

\section{Conclusions}

It is believed that project based learning in the real context is a very effective way for students to build solid professional competences. In this work, different industrial engineering students' teams had to go through real projects in industry under a project based learning framework. In this context, students' teams had to identify problems or opportunities for improvement, and develop effective engineering solutions for companies. This article reports several effective solutions in ergonomics and lean manufacturing areas, with very good results in terms 
of performance and ergonomic improvement according to feedback from teachers and professionals from those companies. The presented solutions in lean manufacturing areas included OEE monitoring implementation, OEE improvement, setup reduction through SMED, cell layout, balancing and flow improvement, and Internal logistics systems improvements. In the ergonomics and human factors related areas, solutions included physical environment improvements, manual material handling improvements, critical postures reduction and accident prevention.

This work presented a contribution for the development of projects in interaction with industries, showing that it is possible to create learning environments encompassing real industrial contexts. These environments create the opportunity for students to identify and define real industrial problems and propose viable solutions. Furthermore, these projects are developed in a context of curricular integration of five courses, which enrich the students' learning that have the opportunity to solve problems of a higher complexity with the help of several teachers with expertise in different knowledge areas.

The feedback from professionals of the companies involved is very positive as can be shown in statements such as " 1 think it makes perfect sense, these projects are an added value for the university, for the companies, for the labour market, and Portugal needs it!”

\section{Acknowledgements}

This work was funded by COMPETE-POCI-01-0145-FEDER-007043 and FCT-UID-CEC-00319-2013.

\section{References}

Accreditation Board for Engineering and Technology. (2013). Criteria for accrediting engineering programs: effective for reviews during the 2014-2015 accreditation cycle. Baltimore: ABET. Retrieved in 12 February 2016, from http://www.abet.org/eac-criteria-2014-2015/

Bellmunt, 0. G., Miracle, D. M., Arellano, S. G., Sumper, A., \& Andreu, A. S. (2006). A distance PLC programming course employing a remote laboratory based on a flexible manufacturing cell. IEEE Transactions on Education, 49(2), 278-284. http://dx.doi.org/10.1109/ TE.2006.873982.

Chinowsky, P. S., Brown, H., Szajnman, A., \& Realph, A. (2006). Developing knowledge landscapes through project-based learning. Journal of Professional Issues in Engineering Education and Practice, 132(2), 118-124. http://dx.doi.org/10.1061/(ASCE) 10523928(2006) 132:2(118).

Chung, P., Yeh, R. C., \& Chen, Y. C. (2016). Influence of problem-based learning strategy on enhancing student's industrial oriented competences learned: an action research on learning weblog analysis. International Journal of Technology and Design Education, 26(2), 285-307. http://dx.doi.org/10.1007/s10798-015-9306-3.

Crosthwaite, C., Cameron, l., Lant, P., \& Litster, J. (2006). Balancing Curriculum Processes and Content in a Project Centred Curriculum. In Pursuit of Graduate Attributes. Education for Chemical Engineers, 1(1), 39-48. http://dx.doi.org/10.1205/ece.05002.

Deshpande, A. A., \& Huang, S. H. (2011). Simulation games in engineering education: a state-of-the-art review. Computer Applications in Engineering Education, 19(3), 399-410. http://dx.doi.org/10.1002/cae.20323.

Elsevier. (2016). About Scopus. Amsterdam. Retrieved in 12 February 2016, from https://www.elsevier.com/solutions/scopus

European Commission. (2007). Modernising universities. Summaries of EU legislation. Bruxells: EU. Retrieved in 12 February 2016, from http://eur-lex.europa.eu/legal-content/EN/TXT/?qid=1432585582363\&uri=URISERV:c11089

Fernandes, S., Mesquita, D., Flores, M. A., \& Lima, R. M. (2014). Engaging students in learning: findings from a study of project-led education. European Journal of Engineering Education, 39(1), 55-67. http://dx.doi.org/10.1080/03043797.2013.833170.

Graaff, E. d., \& Kolmos, A., editors. (2007). Management of change: Implementation of problem-based and project-based learning in engineering. Roterdam: Sense Publishers.

Hansen, R. C. (2001). Overall equipment effectiveness: a powerful production maintenance tool for increased profits. New York: Industrial Press Inc.

Healy, A., Perkmann, M., Goddard, J., \& Kempton, L. (2014). Measuring the impact of university-business cooperation: final report. Luxembourg: Publications Office of the European Union. Retrieved in 12 February 2016, from http://bookshop.europa.eu/en/ measuring-the-impact-of-university-business-cooperation-pbNC0214337/

Hung, l. W., Choi, A. C. K., \& Chan, J. S. F. (2003). An Integrated Problem-Based Learning Model for Engineering Education. International Journal of Engineering Education, 19(5), 734-737.

Institute for Higher Education Policy. (2008). EUR-ACE framework standards for the accreditation of engineering programmes. Washington, DC: lHEP. Retrieved in 12 February 2016, from http://www.ihep.org/assets/files/gcfp-files/EUR-ACESTANDARDS.pdf

Institute of Industrial Engineers. (2012). Industrial Engineering Standards in Europe - IESE. Retrieved in 12 February 2016, from http:// www.iie.ie/\#/iese-report/4570401227

Kanigolla, D., Cudney, E. A., Corns, S. M., \& Samaranayake, V. A. (2013). Project based learning for quality and six sigma education. International Journal of Six Sigma and Competitive Advantage, 8(1), 51-68. http://dx.doi.org/10.1504/1JSSCA.2013.059777.

Kanigolla, D., Cudney, E. A., Corns, S. M., \& Samaranayake, V. A. (2014). Enhancing engineering education using project-based learning for lean and six sigma. International Journal of Lean Six Sigma, 5(1), 45-61. http://dx.doi.org/10.1108/1JLSS-02-2013-0008.

Kim, M. S. (2015). A conceptual framework to develop a project management system with multidisciplinary consilience in the capstone design course. Global Journal of Engineering Education, 17(2), 53-60. 
Kolmos, A., \& Holgaard, J. E. (2010). Responses to problem based and project organised learning from industry. International Journal of Engineering Education, 26(3), 573-583.

Lau, H. Y. K., \& Mak, K. L. (2004). The virtual company: a re-configurable open shell for problem-based learning in industrial engineering. Computers \& Industrial Engineering, 47(2-3), 289-312. http://dx.doi.org/10.1016/j.cie.2004.08.002.

Lau, H. Y. K., \& Mak, K. L. (2005). A configurable e-learning system for industrial engineering. International Journal of Engineering Education, $21(2$ PART 1), 262-276.

Lau, H. Y. K., Mak, K. L., \& Ma, H. (2006). IMELS: An e-learning platform for industrial engineering. Computer Applications in Engineering Education, 14(1), 53-63. http://dx.doi.org/10.1002/cae.20067.

Le Boterf, G. (1997). De la compétence à la navigation professiionelle. Paris: Les Éditions d'Organisation.

Lima, R. M., Dinis-Carvalho, J., Flores, M. A., \& Hattum-Janssen, N. (2007). A case study on project led education in engineering: students' and teachers' perceptions. European Journal of Engineering Education, 32(3), 337-347. http://dx.doi.org/10.1080/03043790701278599.

Lima, R. M., Mesquita, D., \& Flores, M. A. (2014). Project approaches in interaction with industry for the development of professional competences. In: Proceedings of the Industrial and Systems Engineering Research Conference (ISERC 2014), Montréal, Canada.

Lima, R. M., Mesquita, D., \& Rocha, C. (2013). Professionals' demands for Production engineering: analysing areas of professional practice and transversal competences. In: Proceedings of the 22th International Conference on Production Research (ICPR 22), Foz do lguaçu, Brazil.

Lima, R. M., Mesquita, D., Amorim, M., Jonker, G., \& Flores, M. A. (2012). An analysis of knowledge areas in industrial engineering and management curriculum. International Journal of Industrial Engineering and Management, 3(2), 75-82.

Lima, R. M., Mesquita, D., Dinis-Carvalho, J., \& Sousa, R. M. (2015). Promoting the interaction with the industry through project-based learning. In: Proceedings of the 7th International Symposium on Project Approaches in Engineering Education (PAEE), part of International Joint Conference on the Learner in Engineering Education (IJCLEE 2015), San Sebastian, Spain.

Massey, A. P., Ramesh, V., \& Khatri, V. (2006). Design, development and assessment of mobile applications: The case for problem-based learning. IEEE Transactions on Education, 49(2), 183-192. http://dx.doi.org/10.1109/TE.2006.875700.

McCarthy, M., Seidel, R., \& Tedford, D. (2004). Developments in project and multimedia-based learning in manufacturing systems engineering. International Journal of Engineering Education, 20(4), 536-542.

Mesquita, D. (2015). O currículo da formação em Engenharia no âmbito do processo de Bolonha: desenvolvimento de competências, perfil profissional e empregabilidade na perspetiva dos docentes, dos estudantes e dos empregadores (Tese de doutorado). Universidade do Minho, Braga.

Mesquita, D., Lima, R. M., Flores, M. A., Marinho-Araujo, C., \& Rabelo, M. (2015). Industrial engineering and management curriculum profile. Developing a Framework of Competences International Journal of Industrial Engineering and Management, 6(3), $121-131$.

Paten, C. J. K., Palousis, N., Hargroves, K., \& Smith, M. (2005). Engineering sustainable solutions program: Critical literacies for engineers portfolio. International Journal of Sustainability in Higher Education, 6(3), 265-277. http://dx.doi.org/10.1108/14676370510607232.

Pomales-García, C., \& Barreto, K. C. (2014). Comparative analysis of student self-reflections on course projects. European Journal of Engineering Education, 39(6), 685-699. http://dx.doi.org/10.1080/03043797.2014.895706.

Powell, P. C., \& Weenk, W. (2003). Project-led engineering education. Utrecht: Lemma.

Shingo, S. (1985). A revolution in manufacturing: the SMED system. Cambridge: Productivity Press.

Soares, F. O., Sepúlveda, M. J., Monteiro, S., Lima, R. M., \& Dinis-Carvalho, J. (2013). An integrated project of entrepreneurship and innovation in engineering education. Mechatronics, 23(8), 987-996. http://dx.doi.org/10.1016/j.mechatronics.2012.08.005.

United Nations Educational, Scientific and Cultural Organization. (2010). Engineering: issues, challenges and opportunities for development. Retrieved in 12 February 2016, from http://unesdoc.unesco.org/images/0018/001897/189753e.pdf

$\mathrm{Xu}, \mathrm{X}$., \& Duhovic, M. (2004). Computer-aided concurrent environment for manufacturing education. International Journal of Engineering Education, 20(4), 543-551.

Zabalza, M. (2011). El Practicum en la formación universitaria: estado de la cuestión (practicum in higher education: state of the art). Revista de Educación, (354), 21-43.

Received: Dec. 03, 2016

Accepted: Feb. 13, 2017 